\title{
Development of Turf-type Poa pratensis L. Germplasm for Seed Production without Field Burning
}

\author{
By William Johnston ${ }^{*}$ \\ Richard Johnson ${ }^{\dagger}$ \\ Charles Golob \\ Kathleen Dodson ${ }^{+}$ \\ Matthew Nelson \\ Gwen Stahnke \\ Elizabeth Guertal
}

Open-field burning of Kentucky bluegrass (Poa pratensis L.) postharvest residue, which maintains grass seed yield and stand longevity, has been eliminated in Washington and is restricted in Idaho and Oregon, USA. Our objective was to develop Kentucky bluegrass germplasm that has sustainable seed yield without field burning while maintaining acceptable turfgrass quality for use as an amenity grass. From the USDA/ARS Poa pratensis L. Plant Introduction (PI) collection, 228 accessions were evaluated in a field trial and a core collection was developed. This collection was then evaluated in seed production and turfgrass trials and those possessing both good seed yield without field burning and turfgrass quality were identified and planted in a space-plant nursery at Pullman, WA. The eight PI accessions and two commercial cultivars checks were evaluated over a 2-year period and individual plants were reselected within each accession, or check, with the highest seed weight, highest seeds panicle ${ }^{-1}$, highest panicle number area ${ }^{-1}$, and highest seed yield. Turfgrass plots were established in 2006, 2009, and 2010 at Pullman, WA, Auburn, AL, and Puyallup, WA, respectively. Seed production plots (irrigated and non-irrigated) were established at Pullman in 2007. Selection for seed yield components had a variable response and seed yield was more dependent on accession. PI 368241, selection panicles area ${ }^{-1}$, and Kenblue, selection seeds panicle ${ }^{-1}$, had the best sustainable (four

\footnotetext{
*Professor, Washington State University, USA.

${ }^{\dagger}$ Researcher, Washington State University, USA.

${ }^{\ddagger}$ Researcher, Washington State University, USA.

${ }^{+}$Senior Turfgrass Scientist, Jacklin Seed by Simplot, USA.

Agronomist, Grigg Brothers, USA.

-Associate Professor, Walla Walla Community College, USA

Professor, Auburn Univeristy, USA
} 
harvests) seed yield without field burning in both non-irrigated and irrigated seed production plots. Both had fair turfgrass quality, whereas PI 371775, selection seeds panicle ${ }^{-1}$, had good turfgrass quality while maintaining good seed yield with irrigation. These selections have been harvested for seed increase (2012-2014) and germplasm probably will be released by 2015.

\section{Introduction}

Kentucky bluegrass (Poa pratensis L.) seed production in the United States is primarily located in the inland Pacific Northwest, with the major production in the states of Washington, Oregon, and Idaho (Ensign et al., 1989). Without post-harvest residue removal in late summer or early autumn, Kentucky bluegrass usually exhibits a sharp reduction in seed production in the following crop (Lamb and Murray, 1999). Since the 1950s, the most effective means of removing post-harvest residue from a Kentucky bluegrass seed field has been open-field burning (Hickey and Ensign, 1983). However, air quality issues associated with smoke from field burning is a major health concern in the Pacific Northwest. In 1998, essentially a total ban on open-field burning of Kentucky bluegrass crop residue for seed grown for turf or forage was implemented in Washington and restrictions are in place in Idaho and Oregon. Without post-harvest burning seed yield decreases over time, which has forced growers to use shorter rotations to maintain yield; however, this comes with higher inputs and increased soil erosion. Lower seed production with non- burn management is threatening the Kentucky bluegrass seed production industry in the Pacific Northwest. To address this issue, we initiated a program to identify Kentucky bluegrass germplasm that would have sustainable seed yield without field burning. In a multi-year study we evaluated the USDA/ARS Poa pratensis L. collection and developed a core collection (Nelson, 1996), identified germplasm that has improved seed production without open-field burning of post-harvest residue (Johnson et al., 2003), reselected within that germplasm (Johnson et al., 2010), and established turfgrass and seed production trials (Dodson, 2008) that have been evaluated over several years (Johnston et al., 2012). Three selections are currently in seed increase (Johnston et al., 2014) and potentially germplasm will be released by 2015 for commercial cultivation.

\section{Objective}

Develop high yielding turf-type Kentucky bluegrass germplasm that can be grown for several years (minimum of four harvests) without open-field burning of post-harvest residue. 


\section{Materials \& Methods}

This long-term study initially evaluated 228 bluegrasses from the USDA/ARS Poa pratensis L. Plant Introduction collection at Pullman, WA and developed a core collection of 22 PI accessions (Nelson, 1996; Johnston et al., 1997). These accessions plus 17 commercial cultivars were evaluated for several years (Johnson et al., 2003) and eight PI accessions (plus two commercial check cultivars, 'Kenblue' and 'Midnight') representing germplasm that has good seed yield without field burning while maintaining turfgrass quality were identified. For these 10 selections, seed yield parameters were evaluated over a 2-yr period and individual plants were reselected within each accession, or check, with the highest seed weight, highest seed panicle ${ }^{-1}$, highest panicles area ${ }^{-1}$, and highest seed yield (Johnson et al., 2010). These 40 selections plus a base population of seed from the USDA/ARS collection were planted in turf plots in 2006 and non-irrigated and irrigated seed production plots in 2007 at Pullman, WA (Dodson, 2008). There were 150 plots in each trial (50 entries x 3 replications). Additional turfgrass trials were established at Auburn, AL and Puyallup, WA in 2009 and 2010, respectively. Turfgrass trials were evaluated according to the National Turfgrass Evaluation Program (NTEP) protocol. Seed production plots were harvested (2008-2011), threshed, cleaned, and seed yield was determined (Johnston et al., 2012). The 50 entries were culled over several years and the 4-yr means of seed yield vs. turfgrass quality for the remaining selections are presented (Figure 1 and 2). Seed increase plots were established in 2011 and harvested in 2012, 2013, and 2014 (Johnston et al., 2014).

Figure 1. Non-irrigated Kentucky Bluegrass Seed Yield (2008-2011) vs. Turfgrass Quality (2007-2010) at Pullman, WA. Turfgrass Quality rated 1 to 9; 9 = excellent

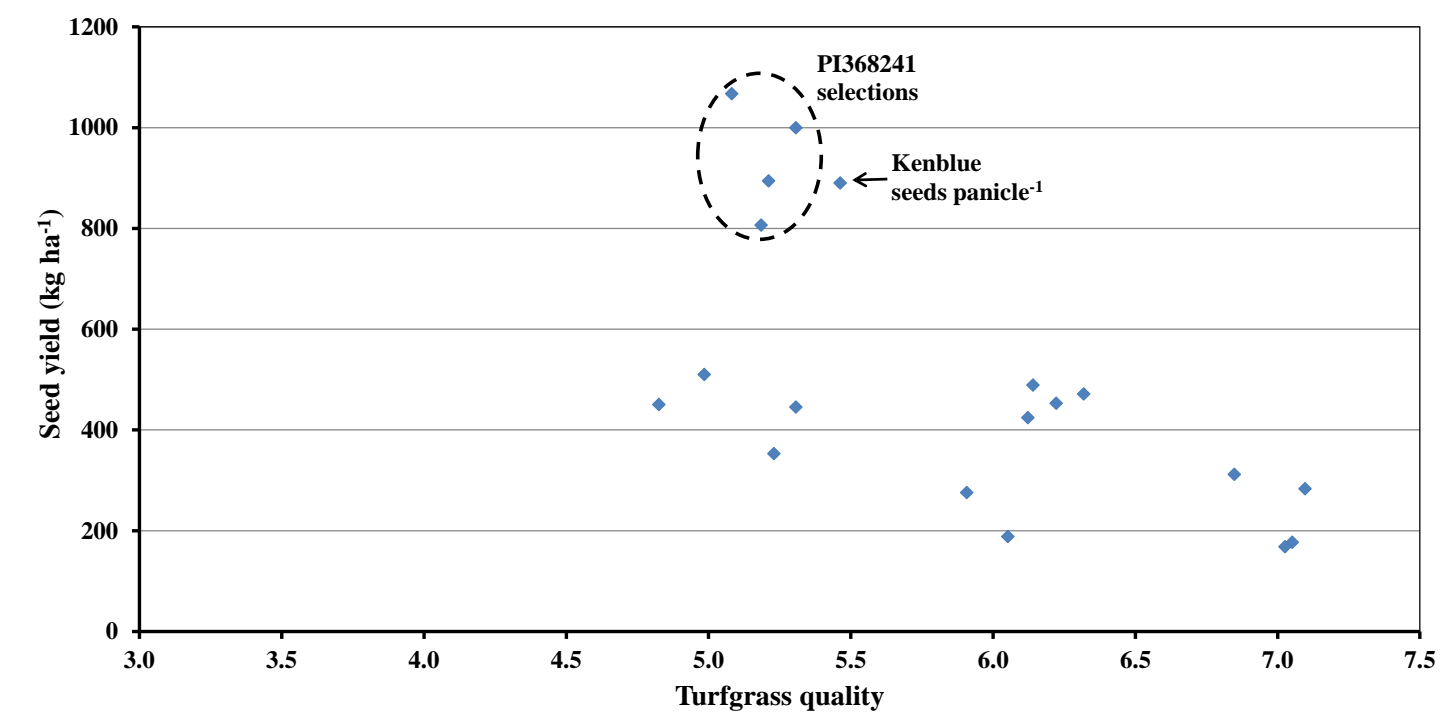


Figure 2. Irrigated Kentucky Bluegrass Seed Yield (2008-2011) vs. Turfgrass Quality (2007-2010) at Pullman, WA. Turfgrass Quality rated 1 to 9; $9=$ Excellent

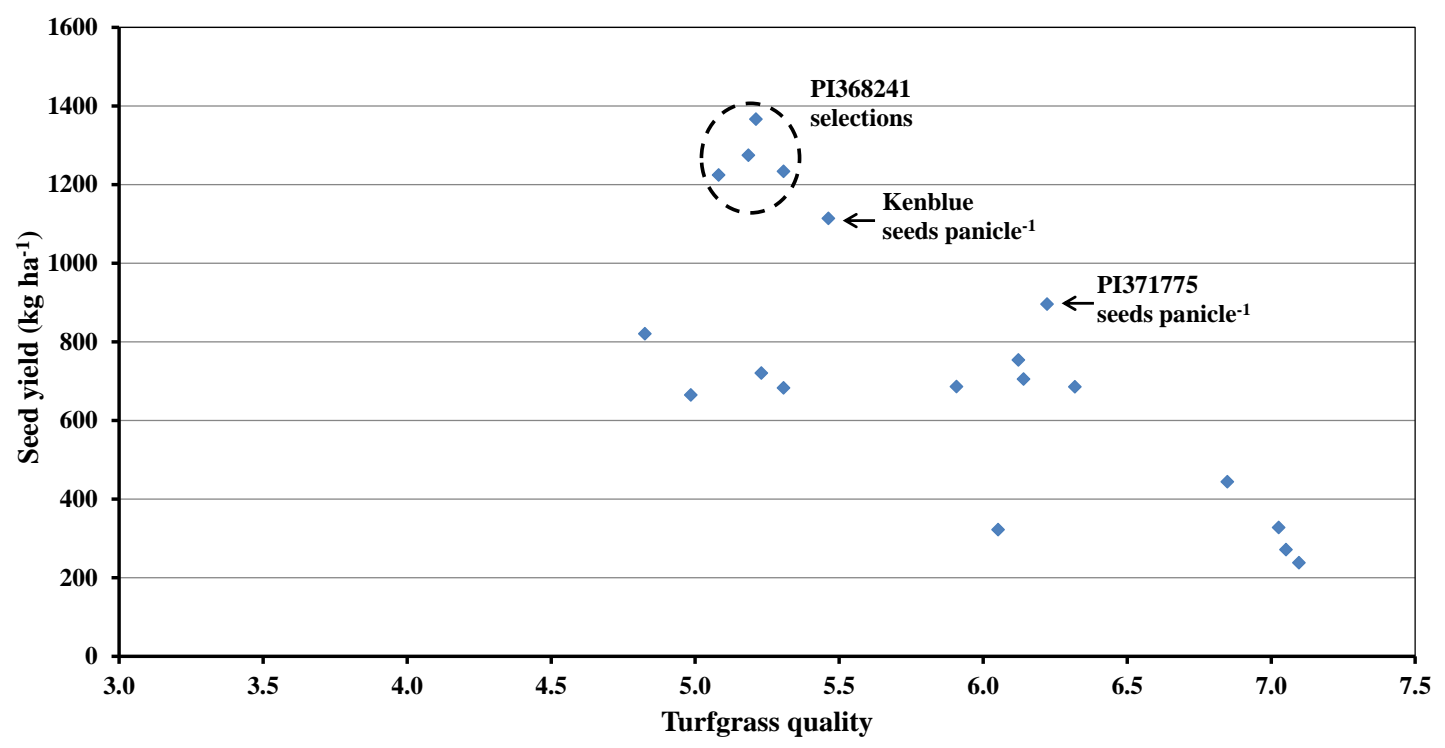

\section{Results \& Discussion}

\section{Evaluation of the USDA/ARS Kentucky Bluegrass Collection}

To estimate diversity within the USDA/ARS Plant Introduction collection of Kentucky bluegrass, 228 accessions and 17 commercially available cultivars were evaluated for turfgrass and seed production parameters during 1994 and 1995. Significant variability was observed for all phenotypic and agronomic traits. Wide variation existed in seed yield and growth habit (Nelson, 1996). The collection was characterized by a representative core utilizing cluster analysis (Ward's method) (Nelson, 1996; Johnston et al., 1997). In addition to the phenotypic-agronomic core, random amplified polymorphic DNA markers (RAPD) were used to analyze the collection and develop a RAPD-based core subset. The correlation between agronomic and molecular distance matrices was highly significant, indicating that data from the different types of analysis corresponded well with each other (Johnson et al., 1999; Johnson et al., 2002).

\section{Residue Management and Turf Evaluation}

Two years of field testing of the core collection (22 accessions) plus 17 selected accessions not in the core, and nine commercial cultivars ('Dawn', 'Victa'. 'Kenblue', 'Monopoly', 'Mystic', 'Julia', 'Eclipse', 'Park', and 'Midnight') produced a wide range of values for turf and seed production parameters. With respect to seasonal turfgrass quality (rated 1-9, with 9excellent), the nine commercial cultivars received a mean rating of 6.3 ; mean seed yield was $1208 \mathrm{~kg} \mathrm{ha}^{-1}$. Three of the 22 core accessions (14\%) achieved these "benchmark" levels, while only one $(6 \%)$ of the selected accession performed as well. Thus, the core collection proved useful in identifying 
accessions with both high turfgrass quality and seed production (Johnston and Johnson, 2000; Johnson et al., 2003).

\section{Selection for Diversity in Seed Yield Components}

Eight PI accessions and two check cultivars ('Kenblue' and 'Midnight'), representing germplasm that had good seed yield without field burning while maintaining turfgrass quality in turf trials, were evaluated over a 2 -yr period in a space plant nursery during 2002 and 2003 (Johnson et al., 2010). Individual plants were reselected within each accession, or check, with the highest seed weight, highest seed panicle ${ }^{-1}$, highest panicles $\operatorname{area}^{-1}$, and highest seed yield. Variation between and within accessions was identified (Johnson et al., 2010), so the potential exists for plant selection and enhancement.

\section{Turfgrass and Seed Production Trials}

Following selection, field testing was done to determine if any increase in seed yield will be maintained under non-burn residue management systems. For some entries turfgrass quality was resistant to selection, but responded to selection for agronomic seed production characteristics. PI 368241, selection panicles $\operatorname{area}^{-1}$, and Kenblue, selection seeds panicle ${ }^{-1}$, had good seed yield both irrigated and non-irrigated and fair turfgrass quality at Pullman, WA (Fig. 1 and 2). PI 371775, selection seeds panicle ${ }^{-1}$, had good turfgrass quality and good yield with irrigation (Fig. 2, Table 1) (Johnston et al., 2014). Kentucky bluegrass is not recommended as a turfgrass for western WA; however, PI 371775 , selection seeds panicle ${ }^{-1}$ had acceptable quality at Puyallup, WA. It may also possess stress tolerance, as all PI 371775 entries placed in the top $10 \%$ for turfgrass quality among the 50 entries during a 2 -yr turfgrass trial at Auburn, AL.

\section{Breeder Seed Increase}

Seed increase plots were harvested in 2012, 2013, and 2014 (2014 data not presented) at Pullman, WA (Table 1) (Johnston et al., 2014). In the Pacific Northwest, USA, Kentucky bluegrass seed yields in commercial fields were considerable below average in 2013 (Jacklin and Dunham, 2014). It will be interesting to see if the yields in the dryland seed increase plots were following the regional trend in 2013, or if they will rebound in seed yield in 2014. 
Table 1. Kentucky Bluegrass Germplasm Seed Yield and Turfgrass Quality at Pullman, WA

\begin{tabular}{|c|c|c|c|c|c|c|}
\hline \multirow{3}{*}{$\begin{array}{l}\text { Cultivar } \\
\text { or PI\# }\end{array}$} & \multirow{3}{*}{$\begin{array}{l}\text { Selection } \\
\text { parameter }\end{array}$} & Turfgrass quality $^{1}$ & \multicolumn{2}{|c|}{ Seed yield $\left(\mathrm{kg} \mathrm{ha}^{-1}\right)$} & \multirow{2}{*}{\multicolumn{2}{|c|}{$\begin{array}{l}\text { Seed increase plots } \\
\text { Seed yield }\left(\mathrm{kg} \mathrm{ha}^{-1}\right)\end{array}$}} \\
\hline & & \multirow{2}{*}{$\begin{array}{l}\text { 5-yr mean } \\
\text { Pullman }\end{array}$} & \multirow{2}{*}{$\begin{array}{c}\text { 4-yr mean } \\
\text { Non-irrigated }\end{array}$} & \multirow{2}{*}{$\begin{array}{l}\text { 4-yr mean } \\
\text { Irrigated }\end{array}$} & & \\
\hline & & & & & 2012 & 2013 \\
\hline Midnight & Elite-type check & $7.1 \mathrm{a}^{2}$ & $152 \mathrm{c}$ & $272 \mathrm{~d}$ & & \\
\hline Kenblue & Common-type check & $5.3 \mathrm{c}$ & $446 \mathrm{~b}$ & $681 \mathrm{c}$ & & \\
\hline Kenblue & Seeds panicle $^{-1}$ & $5.4 \mathrm{c}$ & $890 \mathrm{a}$ & $1114 \mathrm{ab}$ & $1352^{3}$ & $1020^{3}$ \\
\hline 371775 & Seeds panicle $^{-1}$ & $6.2 \mathrm{~b}$ & $452 \mathrm{~b}$ & 896 bc & $816^{4}$ & $1072^{4}$ \\
\hline 368241 & Panicles area $^{-1}$ & $5.1 \mathrm{~d}$ & $1000 \mathrm{a}$ & $1234 \mathrm{a}$ & $1046^{3}$ & $754^{3}$ \\
\hline \multicolumn{7}{|c|}{${ }^{1}$ Turfgrass quality rated 1 to $9 ; 9=$ excellent. } \\
\hline
\end{tabular}

\section{Conclusions}

During the course of this long-term study we have determined that accessions in the UDSA/ARS Poa pratensis L. Plant Introduction collection could be differentiated based on phenotypic and agronomic data and a core collection was developed (Nelson, 1996; Johnston et al., 1997). In the residue management and turfgrass evaluation trials, accessions were identified that maintained good seed yield when post-harvest residue was baled and removed and also possessed good turfgrass quality (Johnson et al, 2003). In a spaceplant study, variation between and within accessions was identified (Johnson et al., 2010); therefore, the potential exists for plant selection and enhancement. In seed production (irrigated and non-irrigated) and turfgrass trials, selection for seed yield components had a variable response; seed yield was primarily dependent on accession (Dodson, 2008). PI 368241, selection panicles area ${ }^{-1}$, and Kenblue, selection seeds panicle ${ }^{-1}$, had good seed yield both irrigated and non-irrigated and fair turfgrass quality at Pullman, WA. PI 371775, selection seeds panicle ${ }^{-1}$, had good turf quality and good seed yield with irrigation (Johnston et al., 2014). Seed increase of these three selections is currently on going at Pullman, WA and germplasm will potentially be released by 2015 .

\section{Acknowledgments}

The authors would like to acknowledge the USDA special grant "Grass Seed Cropping Systems for a Sustainable Agriculture", the Washington State Department of Ecology Agricultural Burning Practices Research Task Force, and the Washington State Turfgrass Seed Commission for partially funding this research. 


\section{References}

Dodson, K.L. 2008. Development of Kentucky bluegrass (Poa pratensis L.) for nonburn seed production. M.S. thesis. Washington State Univ., Pullman.

Ensign, R.D., D.O. Everson, K.K. Dickinson, and R.L. Woollen. 1989. Agronomic and botanical components associated with seed productivity of Kentucky bluegrass. Crop Sci. 29:82-86.

Hickey, V.G., and R.D. Ensign. 1983. Kentucky bluegrass seed production characteristics as affected by residue management. Agron. J. 75:107-110.

Jacklin, G., and R. Dunham. 2014. 2014/2015 grass seed forecast. Jacklin Seed by Simplot Research Newsflash. Vol. 17(3):1-2.

Johnson, R.C., W.J. Johnston, F.B. Bertoli, and C.T. Golob. 2010. Seed yield, development, and variation in diverse Poa pratensis accessions. Crop Sci. 50:337-344.

Johnson, R.C., W.J. Johnston, and C.T. Golob. 2003. Residue management, seed production, crop development, and turf quality in diverse Kentucky bluegrass germplasm. Crop Sci. 43:1091-1099.

Johnson, R.C., W.J. Johnston, C.T. Golob, M.C. Nelson, and R.J. Soreng. 2002. Characterization of the USDA Poa pratensis collection using RAPD markers and agronomic descriptors. Genetic Resources and Crop Evolution 49:349-361.

Johnson, R.C., W.J. Johnston, M.C. Nelson, C.J. Simon, and C.T. Golob. 1999. Core utilization and development - an example with Poa pratensis L. Core Collections for Today and Tomorrow. Int. Plant Genetic Resources Inst. p. 49-60.

Johnston, W.J., and R.C. Johnson. 2000. Washington State and the USDA work to preserve and clarify the rich diversity of Kentucky bluegrass. Diversity 16(1\&2):30-32.

Johnston, W.J., R.C. Johnson, and C.T. Golob. 2012. Kentucky bluegrass germplasm evaluation for seed production without open-field burning. ASA-CSSA-SSSA abstracts. Cincinnati, OH.

Johnston, W.J., R.C. Johnson, and C.T. Golob. 2014. Kentucky bluegrass germplasm for turf and seed production. In Washington State Univ. Crop and Soil Sciences Dryland Field Day abstracts. Pullman, WA.

Johnston, W.J., M.C. Nelson, R.C. Johnson, and C.T. Golob. 1997. Phenotypic evaluation of Kentucky bluegrass (Poa pratensis L.): USDA/ARS Plant Introduction germplasm collection. Int. Turf. Soc. Res. J. 8:305-311.

Lamb, P.F., and G.A. Murray. 1999. Kentucky bluegrass seed and vegetative responses to residue management and fall nitrogen. Crop Sci. 39:1416-1423.

Nelson, M.C. 1996. Development of a Kentucky bluegrass core collection: phenotypic evaluation of the USDA/ARS Plant Introduction germplasm collection. M.S. thesis. Washington State Univ. 
